\title{
ISLAMIC EDUCATION WITH REFERENCE TO PONDOK IN PATANI: SOME REFLECTIONS
}

\author{
Sulaiman Dorloh ${ }^{1}$ \\ Department of Islamic Studies, Faculty of Human Sciences, \\ Sultan Idris Education University (UPSI), Perak, Malaysia. \\ (Email: dsulaiman@fsk.upsi.edu.my) \\ Ibrahim Hashim ${ }^{2}$ \\ Department of Islamic Studies, Faculty of Human Sciences, \\ Sultan Idris Education University (UPSI), Perak, Malaysia \\ (Email: ibrahim@fsk.upsi.edu.my)
}

Received date: $28-11-2019$

Revised date: 29-11-2019

Accepted date: 02-12-2019

Published date: 10-12-2019

To cite this document: Dorloh, S., \& Hashim, I. (2019). Islamic Education with Preference to Pondok in Patani: Some Reflections. International Research Journal of Syariah, Muamalat and Islam, 1(2), 46-53.

DOI: 10.35631 irjsmi.12006

\begin{abstract}
The purpose of this paper is to discuss Islamic education in Pondok includes textbooks and its curriculums. The Pondok education could not be ignored in the local MalayMuslims society of southern Thailand but the study of Islam at Pondok compared to the study of Islam at the local universities is so far being disturbed. Although there have been attempts to introduce Pondok education in government universities such as Prince of Songkhla University (PSU). There was no attempt to integrate the two systems of education together. To a large extent, the two systems are offered and studied in isolation. The paper concludes that the government should recognize the existence of Pondok education institutions as an alternative choice for the local Malay-speaking population to study Islam in the kingdom. The study suggests that adequate attention has to be given by the authority for the improvement of Pondok education.
\end{abstract}

Keywords: Pondok, Islamic Education, Deep South, Tok Guru

\section{Introduction}

The role of Islam in the southern border provinces of Thailand especially in the field of Islamic studies shows that the importance of Islamic education ${ }^{1}$ has grown quite substantially.

\footnotetext{
1 The term "Islamic education" in this paper is applied for the Islamic courses offered by the universities, colleges, private religious institutions including madrasah and pondok in Thailand while the term " Islamic studies" is used for the Islamic subjects offered by the College of Islamic Studies, PSU, Pattani Campus only. In this paper the author will discuss Islamic subjects offered in pondok.
} 
In the past, the studies in pondoks ${ }^{2}$ - the systems of traditional Islamic religious learning and Islamic Private Religious Schools-madrasah were meant for producing tok gurus-religious teachers, ranging from imam, khatib, bilal and $d u a^{\prime}$ '-preachers. The aims of their study Islam at the pondok institution are to preserve Islam and spread Islamic heritage in their locality in the kingdom. Many pondok graduates joined the government sectors and actively involved in democratization process. Among of them was Hon. Aziz Pithakkumpol, the present Thailand Shaikh Islam was among of the pondok southerner graduates. He was a Muslim born in Songkla province surrounded by the Buddhist society and later he decided to travel to the deep south to study Islam and Islamic jurisprudence.

\title{
Historical Background
}

As history has recorded, Patani ${ }^{3}$ has been held as one of the cradles of Islam in South-East Asia ${ }^{4}$ and remained such until it fell into the hands of Siam in $1782 .{ }^{5}$ The study of Islam in Thailand started after the arrival of Islam into Patani ${ }^{5}$ in the tenth century. Most of the learning process was done in and around the mosques and the traditional learning institution called "Pondok'. The well-known pondoks in Patani those days were Pondok Semela (18741957), Pondok Haji Hassan Mak Enggol (1896-1969), Pondok Haji Abdul Rahman bin Muhammad Arshad Dalo (1898-1957), and Pondok Bermin. Some of which for example, Pondok Dalo, Pondok Semla and Pondok Bermin are still exist. ${ }^{6}$ A former Director of Islamic Studies, Dr Hasan Madmarn has observed in his book entitled pondok and madrasah:

\begin{abstract}
"Patani, a southern border province of Thailand was once the center of Islamic education and earned the title cradle of Islam for the Malay Muslim world.... this town, with its well-known pondok and its learned tok guru attracts Muslims from the four southern provinces. Among the wellknown pondok of Patani in those days are Pondok Berming, Pondok Semela, Pondok Dalo, Pondok Haji Mak Dagae, and Pondok Babayeh." 7
\end{abstract}

Since the aims of pondok institutions is to produce ulama- learned scholars in various of field of Islamic disciplines, theology, jurisprudence and ethics. Most importantly, is to educate the Muslims in the south on religious knowledge. As for the technical and academic education

\footnotetext{
${ }^{2}$ The common meaning of the word "Funduq" in Arabic means 'hotel'. Whereas the traditional and classic meaning of "Funduq or Ponok" in Malay language is a 'hut' or a 'cottage'. Hasan Madmarn, History of Islamic Studies in Thailand, Paper presented at the International Seminar on Islamic Studies in The Asian: History, Approaches and future trends, Organized by College of Islamic Studies, Prince of Songkhla University, Patani campus, Thailand on 25-28 June 1998.

${ }^{3}$ The word "Pattani" with double " $t$ " is transliterated from the Thai spelling. It is officially referred to southern border province of the Thai kingdom whereas the word "Patani" with one " $\mathrm{t}$ " is the Malay version indicated the Malay city-state. In this paper, the word "Patani" will be employed. See W.K. Che Man, Muslim Separatism: The Moros of Southern Philippines and the Malay of Southern Thailand Singapore: Oxford University Press, 1990, pp 40-41.

${ }^{4}$ See Teeuw, A. and Wyatt, D.K. (1970) Hikayat Patani (The History of Patani), The Hague, Martinus Nijhoff, p.4

${ }^{5}$ See Couner Bailey and John N. Miksic (1985) History of the Malay Kingdom of Patani, Ohio University, Centre for International Studies, p.4

${ }^{6}$ Pondok Dalo whose teacher was Haji Abdul Rahman(1898-1975),Known as Tok Dalo, Poddok Semela whose teacher was Haji Ismail ,known Tok Semela,Pondok Bermin(1874-1957) whose teacher was Haji Ahmad bin Idris, known as Tok Bermin and Pondok Ma'go whose teacher was Haji Hasan(1896-1969),known as Tok Ma'go Hasan Madmarn,(1999) The Pondok and Madrasah in Patani, Penerbit Universiti Kebangsaan Malaysia, Bangi, p.12

${ }^{7}$ Hasan Madmarn, The Pondok and Madrasah in Patani, UKM press, Bangi, 1999, p.234
} 
they were not taught in the pondoks. Some of the students are given opportunity to undertake the vocational training offered by the government with permission of their tok gurus. Despite there are some constraints as to the system of education in pondok institutions, the study found that there are many Muslim parents still continued to send their children to those pondoks. Perhaps, it can be said, the pondok education are still relevance and it seems to be appealing to the heart and mind of the Muslims in the deep south.

\section{Textbooks Used in the Pondok}

The common medium of instruction in many pondok is Malay- thus the teaching is held in Malay. As a result, books written in Jawi language are considered as main references, but some technical Arabic terms are translated by tok gurus in Malay as well as a pathway to accommodate students to have deeper understandings on certain legal issues. The students are encouraged to write marginal short notes in Jawi in their textbooks. This is because, according Dr Hasan Madmarn most of the Malay-Muslim students ${ }^{8}$ in the deep south are not well-versed in Arabic. They tend to speak Malay in their ordinary conversation and in their daily round of activities because the Malay language is their mother tongue. Moreover, jawi scripts and Malay language are important features of the cultural heritage and becomes medium of instruction of Islamic education in the deep south either in pondoks or Islamic Private Religious Schools. A recent survey conducted by Thailand Ministry of Education revealed that the majority of the Muslims in the south who studied in the government primary and secondary schools are very poor in Thai language. In order to preserve Thai language in the government schools, the adaptation a dual-language system (Thai and Malay) is needed.

The kitab Jawi or religious book written in Arabic script have become the major textbooks for Islamic studies students. Minyatul or Munyatul musolli, a Jawi Patani classical book written by Shaykh Daud Abdullah al-Fatani (1769-1847) is a main textbook. A jawi textbook on Usul al-Din, Faridah al-Faraid was written by Shaikh Wan Ahmad al-Fathoni is commonly read by imams or tok gurus after magrib prayers, Bakuroh al-Amani written by Shaiykh Wan Ismail bin Wan Abdul Qadir(1882-1956) (Pak Da'el Fathoni) as a commentary and explanation on Faridah al-Faraid written by Shaikh Wan Ahmad al-Fathoni. The intention of author of Bakuroh al-Amani was to preserve the bahasa jawi Patani (Jawi's Patani language). The full name of this book is "Bakuroh al-Amani Li Isyarati Awwam Ahl Al-Fathoni". As for the second commentary written by him on Faridah al-Faraid was Syarh Faridah al-Faraid. A work of Pak Da Ail, Bakuroh is currently read by a Shaiykh Ismail Sepanjang on every Satuday morning at the Patani Central Mosque after several requests made by the public. Those who study on Friday at Patani Central Mosque are divided into two groups: the "learners" and the "listeners". The learners are those who study religion seriously and open their books during the time when they are sitting in the mosque. On the contrary, the listeners attend the lessons only to hear the lectures. They will sit on mosque verandah.

\footnotetext{
8 The word "Malays" reflects the major ethnic traits and characteristics of the people as a distinctive ethnic group while the word "Muslim" used as an adjective emphasizes their religion is inseparable from their ethnicity. Thus, one never hears the expression "Malay-Buddhists" or "Malay Christians" used, for they would be self-contradictory. The term Muslim and Malay always complement each other. See Seni Mudmarn, Social Science Research in Thailand: The Case of the Muslim Minority', in Omar Farouk Bajunid (eds), Muslim Social Science in ASEAN, Kuala Lumpur: Yayasan Penataran Ilmu, 1994, p. 32. In the context of the Malaysian social fabric, religions are identifiable with races. The Malays profess Islam to the extent that the constitution declares them as Muslims (Art 160 of the Federal Constitution), Indians usually adhere to Hinduism and the Chinese communities largely profess Buddhism.
} 
In order to develop spirituality among the pondok students, Penawar bagi hati- by Sheikh Abdul Qadir al-Mandili (1910-1965), that discussed the science of ethics and Islamic psychotherapeutic elements is taught to the students in the pondoks.

Besides Jawi literatures some Arabic literatures are frequently consulted, they are as follows:

1. Idah al-Bab li murid al-Nikah bi al- Sawab (The clarifying chapter for him who desires to know the right way of marriage),

2. Furu' al-Masail wa Usul al-Wasail,

3. Al-Fatawa al-Fataniah,

4. Kashf al-Litham Ghayat al-Taqrib, and

5. Baghiyyat al-Tulab li murid ma'rifah al-Ahkam bi al-Sawab

We may notice that all of the above-mentioned Malay textbooks were written in accordance with the Shafi'e school of law. This is because the majority of the Malay-Muslims inhabitants in the deep south adhere to Shafi'e school of jurisprudence. The book entitled Bahjat alMubtadin wa-Farhat al-Mujtadin-the delight of the beginners, and the pleasure of those who seek answer, Shaykh Ahmad Zayn al-Abidin bin Muhammad (1820-1913) observed:

This was a small pamphlet which was compiled quickly and in abbreviated form about the principles of Islamic law and its branches. In addition, a moistener with which beginners can moisten them before entering the ponds of its water-sources. I named this small book Bahjat al-Mubtadin ... with a hope that will be helpful for the young students as well as directing to the desires of all those who are interested. May Allah accept our prayer. ${ }^{9}$

There are four families of Shafi'is figh texts still use in those pondoks namely the texts of Minhaj al-Talibin by al Nawawi( d. 676 A.H), Mugni al-Muhtaj of al-Sharbini ( d.977 A.H) and Nihayat al-Muhtaj of al-Ramili, Kifayat al-Akhyar of Dimashqi ( d.829A.H.), Fath alQarib of Ibn Qasim al-Ghuzzi (d.918 A.H), Hashiyah al-Bajuri of al-Bajuri(d. 1277 A.H.), Fath al-Mu'in of al-Malibari, and I'anat al-Talibin of Sayyid Bakri Bin Sayyid Muhammadal (ca.1300 A.H.). The books mentioned above were used as the major text books in the pondok. This is because the majority of the Malay Muslims in those four provinces adhere to the Shafi'is school of law. ${ }^{10}$

\section{The Scenario Behind the Islamic Education in Pondok}

Pondok in southern Thailand became the preeminent symbol of Malay Muslim Islamic ideals and cultural resistance to the central authorities in Bangkok. It was recorded that, the first attempt was made in the year 1930 to 1940 , these attempts were made by the government of P. Phibun Songkram to assimilate the Malay-Muslim community into Thai society by attempting to change the medium of instruction in Pondok education from Malay to Thai

\footnotetext{
${ }^{9}$ Ibid., p.9.

${ }^{10}$ See Report of Luang Prapai Pittayakhun, p.213; Raymond Scupian, Popular in Thailand, edited by Andrew D.W. Forbes Center for South East Asia Studies, India, n.d.,p.32; Arong Suthasat, Shariah and Codification, ibid.,p.142. See also Isma-ea Alee, Mazhab Shafi'i Dalam Menghadapi Globalisasi: Suatu Pengalaman di Thailand, paper presented at International Seminar on Legal Thought of Al-Shafi'i Madhhab, Universiti Brunei Darussalam, 18-19 January, 2006,p.3; Sulaiman Dorloh, Religious Courts in Thailand : Between Inspiration and Challenge, paper presented in the ISCOL2006(International Seminar on Syariah \& Common Law 2006), organized by Kolej Universiti Islam Malaysia, Palace of the Golden Horses Hotel, 20-21 September, 2006 ,p.95
} 
language. The second attempt was made by the Sarit Thanarat administration in the early 1960s and the third attempt was in the early 1970s. This attempt has largely affected pondoks education entirely.

This situation contributed to the formation of Madrasah-religious schools. In the beginning, religious schools were registered under private (religious) school Act of 1982, which, among other things, the government seek to improve the management and administration of Islamic private schools. After that the Ministry of Education had introduced new policies among other were to improve and legalize the status of the pondok under the Patronage of Islamic Private Schools (PIPS). The primary objectives of this policy are as follows:

1. To bring the pondok education in line with the levels of national education standard and

2. To nurture a better understanding between the government and the people on Islamic education in the region.

In order to materialize the above-mentioned objectives, the Ministry of Education introduced the three new policies. Firstly; to register and legalize the pondok institution through the process of national registration in order to regulate and monitor the pondok education, secondly; to transform the pondok institution into Islamic private schools (IPS) eligible for government funding of $60 \%$ and Thirdly; to refrain the establishment new pondok institutions. $^{11}$

After the implementation of this policy, the study found that 487 pondoks were registered under IPS out of which 426 have become Islamic private schools (IPS) and 61 pondoks have been closed. ${ }^{12}$ A former Director of Islamic Studies, Prince of Songkhla University, Patani campus had rightly observed:

The pondok, as a traditional Islamic institution, stands as an Islamic heritage in the southern Thailand of today, representing the Islamic centre of learning several decades, and it still keeps its status as a Muslim institution. Its function will not stop to produce its roles so far as the Muslim society is in need of it, and its roles in providing Islamic heritage should not be disturbed. The afford of any party, any authority to destroy (wipe out) this center will meet failure. ${ }^{13}$

The adaptation of the national educational curriculum to pondok system of education as proposed by the government will somehow, disturb the system of traditional education that has been transformed by tok guru to the students. Religious schools in Patani are divided into three categories that is unregistered pondok schools and the Islamic private religious school, commonly known as "Madrasah". The second category it was funded by the government as opposed to pondok schools.

\footnotetext{
${ }^{11}$ For more information see Ibrahem Narongraksakhet, Pondok and Their Roles in Preserving Muslim Identity in Southern Border Provinces of Thailand, in Knowledge and Conflict Resolution: The Crisis of the Border Region of Southern Thailand, School of Liberal arts, Walailak University, 2005, p.69.

12 Hasan Madmarn, " The Strategy of The Islamic Education in the South and Southeast Asia: Thailand Experience.' Paper presented at the International Seminar on Muslim Studies: Modernization and Managerialization, Thailand, 19 August 2006, pp.11-12.

${ }^{13}$ Ibid., p.9.
} 
Madrasah received continues support from the government and madrasah developed very well. It started to get a place and the attention of the people to send their children to study religious and academic subjects. They are better in term of management and facilities than pondok schools. Moreover, Islamic private religious schools offer at least two options-Science and Arts stream.

It can be said that Islamic education in southern Thailand can generally be divided into three types, the government-funded schools, half-funded schools-madrasah and non-funded schools (pondok). The table below showing types of Islamic education schools and nature of the study of each school.

Table1: Types of Islamic Education in Southern Thailand

\begin{tabular}{|c|l|l|}
\hline No & \multicolumn{1}{|c|}{ Types of school } & \multicolumn{1}{|c|}{ Nature of study } \\
\hline 1 & Pondok & Opening the book study or tadah kitab \\
\hline 2 & $\begin{array}{l}\text { Islamic Private Education School or } \\
\text { madrasah }\end{array}$ & Islamic and Non-Islamic subjects \\
\hline 3 & Government school & Selected some Islamic subjects \\
\hline
\end{tabular}

Source: D.Medrano, Anthony. (2006), Islamic Education in Southern Thailand: A Photo Essay. Retrieved from scholarshipspace.manoa.hawaii.edu/bitstream/10125/2247/Exp7n2-6\%20Medrano.pdf 30/11/2019.

\section{Curriculum and Method of Teaching in Pondok}

As far as pondok education system is concerned, there is no formal curriculum. As for system of the assessment, it based on the student's ability to read and explain the classical texts, and hence the pondok schools are not accredited by the government. The texts will generally, be read by tok guru after predawn prayers. No lesson after lunch and after 'asr prayer. The lesson will be started after maghrib till midnight. The students learn by way of writing and taking down commentaries and explanations provided by their respective tok gurus on the margin of the book.

Tadah kitab or buka kitab (opening the book) is considered as common method of teaching, by which a tok guru would sit at the centre of a semicircle formed by his students when delivering his lessons. The lessons take place in the mosque. Tadah kitab system of education emphasises on both memorization and understanding. Normally, the session of study will be divided into two sessions, beginners and advanced learners sessions. Tok guru will determine the suitable book to be read in accordance with level of the learners. Some writers, for example Dr Hasan Madmarn, was of the opinion that the syllabus depends on the specialization of tok guru himself. Normally, it will take more than 15 years to complete the entire syllabus.

However, the pondok's syllabus covers Islamic creeds, theology, Jurisprudence, life history of Prophet (PBUH), ethics, Arabic morphology, syntax, interpretation of the tradition of the Prophet, science of Quranic recitation and others. This method of study still continues until today. 
Generally, the pondok education in Patani, representing the kaum tua-older generation group as oppose to modernist group- kaum muda. A leading member of the Kaum Muda group, Tok Guru Ghani who transformed and introduced the modern madrasah into the traditional system of religious education.

\section{Conclusion and Suggestions}

Despite the fact that several attempts had been made by the government to reconstruct, transform and monitor the system of Islamic education in pondoks in the deep south, yet its system of Islamic education still remains in operation until today. The pondok institution play a key role in deepening the Malay-Muslim community's understanding on Islamic heritage. Recent research conducted by the Prince of Songkhla University, Patani campus has found that up to $64 \%$ of the respondents desire general education to be offered for their children in pondoks in order to close the gap between traditional pondok education and modern education. Traditional pondok educations should focus on innovative method of teaching with critical thinking skills rather than indoctrination with a little encouragement of analytical thinking skills. The author suggests that adequate attention has to be given by the authority for the improvement of the pondok education as an Islamic revivalism in the kingdom representing kaum tua (older generation).

\section{References}

Abu Sulayman, A. Hamid. (1989). Islamization of Knowledge: General Principle and Work Plan. Herndon Virginia: Institute of Islamic Thought.

Abu Sulayman, A. Hamid. (1989). Orientation Guidelines for the International Conference on Islamization of Knowledge in Towards Islamization of Disciplines, Herndon Virginia: International Institute of Islamic Thought.

Abdullah, Haji Wan Mohd Shaghir. (1997). Al-Fatawa Fathaniah, Kuala Lumpur, Malaysia: Khazanah Fathaniyah.

A. Malik, Mohd Zamberi. (1994). Patani dalam Tamadun Melayu. Kuala Lumpur: Dewan Bahasa dan Pustaka.

A. Malik, Mohd Zamberi. (1993). Umat Islam Patani: Sejarah dan Politik. Shah Alam, Selangor: Hizbi.

Alee, Isma-ea. (2006). Mazhab Shafi'i Dalam Menghadapi Globalisasi: Suatu Pengalaman di Thailand, Proceedings of the International Seminar on Legal Thought of Al-Shafi'i Madhhab, Universiti Brunei Darussalam, January 18-19.

Bailey, C \& John N. Miksic, J.N. (1985). History of the Malay Kingdom of Patani, Ohio: Ohio University Press.

Ben Hawan, Datok Aziz. (1988). The Educational and Training of Shari'ah Judges and Lawyers, Proceedings of the $5^{\text {th }}$ SEAS Conference, Singapore, February 26-28

Ben Hawan, Datok Aziz. (1990). Kadi di Selatan Thai. Shariah Law Journal, (2).1-3.

Che Man, W.K. (1990). Muslims Separatism: The Moros of Southern Philippines and the Malay of Southern Thailand, Singapore: Oxford University Press.

College of Islamic Studies Prospectus. (n.d). Prince of Songkhla University, Patani Campus, Thailand.

Dorloh, Sulaiman. (2004). Shari'ah and Democracy: The Southeast Asia Experience. In Mutalib, Hussin, Centre for Contemporary Islamic Studies and the Konrad-AdenaurStiftung Foundation, Singapore. Retrieved from: books.google.com.my/book/Islam_and_democracy.html?id=Dny5AAAAIAJ\&redir_e ssc=y $30 / 11 / 2019$ 
Dorloh, Sulaiman. (2006). Religious Courts in Thailand: Between Inspiration and Challenge, Proceedings of the ISCOL2006 (International Seminar on Syariah \& Common Law 2006), Kolej Universiti Islam Malaysia, Palace of the Golden Horses Hotel, 20-21 September 20-21.

Fathi al-Fatani, Ahmad. (2001). Pengantar Sejarah Patani, Kota Bharu: Aman Press Sdn. Bhd.

Hatta, Khrong Chai. (2005). Prawatsat Patani Samai Anachark Boran Thengkan Pokkhrong 7 Huameang. Pattani: Universiti Songkhla Nakharin

Madmarn, Hasan. (1998). History of Islamic Studies in Thailand, Proceedings of The Asian: History, Approaches and Future Trends, College of Islamic Studies, Prince of Songkhla University, Patani Campus, Thailand June 25-28.

Madmarn, Hasan. (2006). The Strategy of The Islamic Education in the South and Southeast Asia: Thailand Experience. Proceedings of The International Seminar on Muslim Studies: Modernization and Managerialization, Thailand, August 19.

Madmarn, Hasan. (1999). The Pondok and Madrasah in Patani, Malaysia,Bangi: Penerbit Universiti Kebangsaan Malaysia.

Madmarn, Seni. (1994). Social Science Research in Thailand: The Case of the Muslim Minority", in Omar Farouk Bajunid, Muslim Social Science in ASEAN, Kuala Lumpur: Yayasan Penataran Ilmu.

Narongraksakhet, Ibrahem. (2005). Pondok and Their Roles in Preserving Muslim Identity in Southern Border Provinces of Thailand, in Knowledge and Conflict Resolution: The Crisis of the Border Region of Southern Thailand, School of Liberal arts, Walailak University.

Omar Chapakia, Ahmad. (2000). Politik Thai dan Masyarakat Islam di Selatan Thailand. Kedah Darul Aman, Malaysia: Pustaka Darussalam.

Pitsuwan, Surin. (1984). Islam and Malay Nationalism: A Case Study of The Malay-Muslims of Southern Thailand. U.S.A: University Microfilms International.

Scupian, Raymond. (n d.,). Popular in Thailand, in Andrew D.W. Forbes. India: Center for South East Asia Studies.

Syukri, Ibrahim. (2002). Sejarah Kerajaan Melayu Patani, Selangor Darul Ehsan: Penerbit UKM.

Teeuw, A. \& Wyatt, D.K. (1970), The History of Patani. The Hague, Martinus Nijhoff. 